\title{
PHYTOCHEMICAL, GAS CHROMATOGRAPHY-MASS SPECTROMETRY PROFILING AND FREE RADICAL SCAVENGING ACTIVITY OF EXOCARPOS LONGIFOLIUS (SANTALACEAE) EXTRACTS
}

\author{
PRAPTIWI*, AHMAD FATHONI \\ Research Center for Biology, Indonesian Institute of Sciences, Jl. Raya Jakarta-Bogor KM. 46, Cibinong, Bogor 16911, Indonesia. \\ Email: praptiwip@yahoo.com
}

Received: 14 March 2018, Revised and Accepted: 04 July 2018

\section{ABSTRACT}

Objective: The objectives of the study were to investigate phytochemical screening and gas chromatography-mass spectrometry (GC-MS) profiling of twigs and leaves of Exocarpos longifolius and its 2,2-diphenyl-1-picrylhydrazyl free radical scavenging activity.

Methods: Phytochemical screening covering saponins, alkaloids, terpenoids, flavonoids, and tannins were carried out by standard methods. The free radical scavenging activity was performed by thin-layer chromatography - bioautography, followed by determining the $\mathrm{IC}_{50}$ values of active extracts. Chemical compounds of active extract were examined by gas chromatography/mass spectrometry.

Results: The phytochemical screening revealed that all extracts have been shown to contain tannins and terpenoids, saponins were found in the methanol extract of twigs, and alkaloids were found in the ethyl acetate extracts of twigs and leaves, while flavonoids were found in the methanol extract and ethyl acetate extracts of twigs and leaves of E. longifolius. Ethyl acetate extract of twigs showed the best of IC ${ }_{50}$ value (15.65 $\left.\mu \mathrm{g} / \mathrm{mL}\right), \mathrm{while}$ ethyl acetate extract of leaves and methanol extract of twigs have strong free radical scavenging activity with $\mathrm{IC}_{50}$ values were 78.59 and $67.24 \mu \mathrm{g} / \mathrm{mL}_{\text {, }}$ respectively. The GC-MS analysis of ethyl acetate extract of twigs has shown the presence of 12 identified compounds, and the main chemical compound is Stigmast-4-en-3-one (21.91\%).

Conclusions: The ethyl acetate extract of E. longifolius showed a very powerful free radical scavenging activity and revealed chemical compounds had been known to have biological activity. It might be used as a natural antioxidant.

Keywords: Exocarpos longifolius, Phytochemical compounds, 2,2-diphenyl-1-picrylhydrazyl, Stigmast-4-en-3-one.

(C) 2018 The Authors. Published by Innovare Academic Sciences Pvt Ltd. This is an open access article under the CC BY license (http://creativecommons. org/licenses/by/4. 0/) DOI: http://dx.doi.org/10.22159/ajpcr.2018.v11i10.25296

\section{INTRODUCTION}

Plants have been used for such a long time in various aspects of human life, including for their primary health care. Utilization of plants as herbal medicine is related to their biologically active compounds, because plants are capable of producing varieties of chemical compounds categorized as secondary metabolites. Kong et al. [1] indicated that plants are rich source of secondary metabolites, such as alkaloids, flavonoids, saponins, steroids, terpenoids, polysaccharides, and tannins. Many of these secondary metabolites have pharmacological and biological activities [2,3] such as free radical scavengers or antioxidant.

Free radicals (superoxide and hydroxyl radicals) are produced in the body during metabolic processes, and in a state of excess will lead to negative effects, including cell death and tissue damage [4], atherosclerosis, coronary heart disease, cancer, and premature aging [5]. On the other hand, the body does not have large amounts of antioxidant reserves, so that the body needs exogenous antioxidants to protect it more efficiently against oxidative stress caused by free radical [6].

Antioxidants are components that can donate an electron to a free radical, and neutralize it [7]. The exogenous antioxidant can be divided into synthetic and natural antioxidants. Natural antioxidants have advantages over synthetic antioxidants which can be obtained easily and economically and have a slight or negligible side effect [8]. Recently, the interests in natural products and environment-friendly antioxidants are looking for as a substitute and various plants contained a massive pool of bioactive compounds [9].

Some species of Santalaceae have been reported to have biological activities. Exocarpos latifolius has yielded exocarpic acid and its analogs as antimycobacterial compounds [10]. Some species of Santalaceae have been reported as potential free radical scavengers such as Viscum album, Osyris quadripartita, and Quinchamali chilensis which correlated with its total phenol $[8,11,12]$.

Exocarpos longifolius is a small tree or shrub belongs to Santalaceae. E. longifolius distributed in Southeast Asia, Australia, and the Pacific Islands. Several plant species from Santalaceae have been known to be potential as an antioxidant. However, the biological potential of Exocarpos as free radical scavenger has not been studied widely. Therefore, this study focused on the chemical compounds and the free radical scavenging activity of various extracts of $E$. longifolius.

\section{METHODS}

\section{Plant material}

Exocarpos longifolius or Kayu Sulaeman (common name) was collected from Batudulang, Batu Lanteh District, West Sumbawa, West Nusa Tenggara. The plant was identified and authenticated at the Herbarium Bogoriense, Botany Division, Research Center for Biology, Indonesian Institute of Sciences.

\section{Sample preparation and extraction}

Twigs and leaves were separated, washed thoroughly under tap water to remove dirt. The samples were cut into small pieces and dried in the oven at $40^{\circ} \mathrm{C}$. The dried samples were ground into powder.

Samples were subsequently extracted with different solvent polarity, namely hexane, chloroform, ethyl acetate, and methanol successively. Samples were macerated with hexane thrice. The filtrate was concentrated with the rotary evaporator (Heidolph WB2000). The 
same steps follow for other solvents. Dried crude extract weighted and extraction yield were calculated as follows: (Weight of extract/weight of original sample) $\times 100 \%$

\section{Phytochemical analysis}

Qualitative phytochemical screening was carried out on ether, chloroform, ethyl acetate, and methanol extract of E. longifolius for the identification of major phytochemical constituents such as saponins, tannins, alkaloids, terpenoids, and flavonoids [13].

\section{Saponins}

The extract is diluted with distilled water and shaken vigorously. The appearance of persistent froth for $1 \mathrm{~min}$ indicates the presence of saponins.

\section{Tannins}

The extract was added with distilled water and then added with ferric chloride $\left(\mathrm{FeCl}_{3}\right)$. The appearance of a dark green color indicates the presence of tannins.

\section{Alkaloids}

The extract was added with $2 \%$ sulfuric acid, stand for 2 min. A few drops of Dragendroff's reagent were added. The appearance of orange precipitate indicates the presence of alkaloids.

\section{Terpenoids}

The extract was added with chloroform and added with concentrated sulfuric acid from the side of the test tube. The appearance of the reddish brown rings at the junction of two layers indicates the presence of terpenoids.

\section{Flavonoids}

The extract added with methanol and heated at $50^{\circ} \mathrm{C}$. After that, it added with magnesium and 4 drops of hydrochloric acid. Appearance of orange-red color indicates the presence of flavonoids

\section{Bioautographic analysis for 2,2-diphenyl-1-picrylhydrazyl (DPPH)} free radical scavenging activity

Ten microliters of hexane, chloroform, ethyl acetate, and methanol extracts $(10 \mathrm{mg} / \mathrm{ml})$ and $(+)$-catechin as standard were transferred on thin-layer chromatography (TLC) plate (Silica gel $\mathrm{GF}_{254}$ ). The TLC plate was air-dried and then sprayed with $0.2 \%$ DPPH in methanol [14]. Observations of DPPH free radical scavenging activity were examined at 30 min after DPPH spraying. The yellowish-white spot around the extract against a purple background on TLC-plate indicating DPPH free radical scavenging activity.

Active extracts with free radical scavenging activity were further analyzed. $10 \mu \mathrm{L}$ of ethyl acetate or chloroform extract was transferred on TLC plate, then developed in mobile phase dichloromethane: methanol $(10: 1)$ to separate the chemical compounds. The active methanol extract was developed in chloroform: methanol:water (6:4:1). The TLC plates were subsequently dried then sprayed with $0.2 \%$ DPPH in methanol. The plates were incubated at room temperature for $30 \mathrm{~min}$. The chemical compounds with DPPH free radical scavenging activity were detected as yellow spots against a purple background.

\section{Determination of $\mathrm{IC}_{50}$}

The extracts with DPPH free radical scavenging activity were further analyzed for their $\mathrm{IC}_{50}$ values by serial dilution method in a- 96 well microplate according to the modified method recommended by Zhou et al. [15]. The test was conducted in triplicates. The working solution of extract was prepared at a concentration of $1000 \mu \mathrm{g} / \mathrm{ml}$ in methanol. Catechin was used as positive control and prepared at a concentration of $1000 \mu \mathrm{g} / \mathrm{ml}$. The DPPH solution in methanol $(0.1 \mathrm{mmol})$ was freshly prepared. Each well within the first row (row A) was added with $100 \mu \mathrm{L}$ of working solution $(1000 \mu \mathrm{g} / \mathrm{ml})$. The following rows were added with $50 \mu \mathrm{L}$ methanol. Then, $50 \mu \mathrm{L}$ of solution in the first row was taken out and transferred into the second row and homogenized. After homogenized, $50 \mu \mathrm{L}$ was taken out and transferred into the next row resulting in serial dilution. In the past row, $50 \mu \mathrm{L}$ was taken out and discarded. After the serial dilution is completed, each well was added with $80 \mu \mathrm{L} 0.1 \mathrm{mmol}$ DPPH. The microplate was incubated for $30 \mathrm{~min}$ at $37^{\circ} \mathrm{C}$ in the dark condition. After the incubation period was completed, the absorbance of each sample was measured at $517 \mathrm{~nm}$ (Varioskan Flash, Thermo Scientific). The value of $\mathrm{IC}_{50}$ was calculated using a linear curve between the concentration of the test sample and the percentage of inhibition.

\section{Gas chromatography-mass spectrometry (GC-MS) analysis}

The chemical compounds of ethyl acetate extract of twigs were identified by GC-MS analysis. It was carried out using a GC-MS (Shimadzu 2010), equipped with Rtx-5MS capillary column (5\% diphenyl/95\% dimethylpolysiloxane, $30 \mathrm{~m}, 0.25 \mathrm{~mm} \mathrm{ID,} 0.25 \mathrm{um} \mathrm{df}$, max. $350^{\circ} \mathrm{C}$, RESTEK, USA). The carrier gas was helium at a flow rate of $2.0 \mathrm{ml} / \mathrm{min}$. The volume of the injected sample was $5 \mu \mathrm{L}$. The injector temperature was $250^{\circ} \mathrm{C}$, and the interface temperature was $300^{\circ} \mathrm{C}$. The initial temperature of the column was $100^{\circ} \mathrm{C}$, and the final temperature was $270^{\circ} \mathrm{C}$. The temperature program: Initial temperature $100^{\circ} \mathrm{C}$, held for $3 \mathrm{~min}$ and then ramping at the rate of $10^{\circ} \mathrm{C} / \mathrm{min}$ up to $270^{\circ} \mathrm{C}$ and held for $18 \mathrm{~min}$ [16]. Identification of chemical components in the extract based on interpretation on mass spectrum of GC - MS using the database of NIST 11 (National Institute Standard and Technology,US) and WILEY 8.

\section{RESULTS}

\section{Qualitative phytochemical analysis}

The qualitative phytochemical analysis was carried out on different solvent from leaves and twigs of E. longifolius (Table 1). Phytochemical screening revealed similar chemical compounds of the leaves and the twigs of E. longifolius. Tannins and terpenoids were present in the hexane and chloroform extracts, while ethyl acetate extracts revealed the presence of tannins, alkaloids, terpenoids, and flavonoids (Table 1).

\section{Detection of DPPH free radical scavenging activity}

The results of DPPH free radical scavenging activity assay of $E$. longifolius twigs and leaves were presented in Fig. 1.

Fig. 1 showed that all of the extracts had active compounds as DPPH free radical scavenger indicated by a yellowish white band. The active

Table 1: Qualitative phytochemical analysis of twigs and leaves of $E$. longifolius

\begin{tabular}{|c|c|c|c|c|c|c|c|}
\hline \multirow[t]{2}{*}{ Compounds } & \multicolumn{4}{|l|}{ Twigs } & \multicolumn{3}{|l|}{ Leaves } \\
\hline & Hexane & Chloroform & Ethyl acetate & Methanol & Hexane & Chloroform & Ethyl acetate \\
\hline Saponin & - & - & - & + & - & - & - \\
\hline Tannin & + & + & + & + & + & + & + \\
\hline Alkaloid & - & - & + & - & - & - & + \\
\hline Terpenoids & + & + & + & + & + & + & + \\
\hline Flavonoids & - & - & ++ & + & - & - & ++ \\
\hline
\end{tabular}

-: Secondary metabolites not detected, +: Secondary metabolites detected. E. longifolius: Exocarpos longifolius 
extracts were further analyzed to determine their potential as free radical scavengers. $\mathrm{IC}_{50}$ values of extracts were presented in Table 2 . Three extracts exhibited in vitro strong free radical scavengers $\left(\mathrm{IC}_{50}\right.$ value $<100 \mu \mathrm{g} / \mathrm{ml}$ ) [17], which were ethyl acetate and methanol extracts of the twigs and ethyl acetate extract of the leaves.

\section{GC-MS profiling of ethyl acetate extract of twigs}

The GC-MS analysis of ethyl acetate extract of the twigs E. longifolius was shown in Fig. 2.

GC-MS analysis of ethyl acetate extract of $E$. longifolius of twigs revealed the presence of 12 identified compounds and stigmast-4-en-3-one $(21.91 \%)$ as the main compound. The identified compounds could be classified into various chemical classes such as fatty acids (methyl palmitate; linoleic acid, methyl ester; alpha linoleic acid, methyl ester; and sebacic acid, ethyl methyl ester); steroids (1-dehydrotestosterone, methyloxime, trimethylsilyl ether; Androst-11-en-17-one, 3-formyloxy-, (3.alpha.,5.alpha.)-; and stigmast-4-en-3-one); acyclic diterpene (phytol, acetate); alcohol (tetracontane-1,40-diol); benzofuran derivative (2-isopropenyl-4,4,7a-trimethyl-2,4,5,6,7,7a-hexahydro-benzofuran6-ol); acetamide derivative (N1-(8-Methyl-8-azabicyclo[3.2.1]oct3-yl)-2-(2-methoxyphenyl)acetamide); and thiophene derivative (4-Acetyloxyimino-6,6-dimethyl-3-methylsulfanyl-4,5,6,7-tetrahydrobenzo[c]thiophene-1-carboxylic acid methyl ester). Some of these compounds have been reported by other researchers to have biological activity (Tables 3 and 4).

\section{DISCUSSIONS}

Phytochemical screening is important to ascertain the chemical components in the extract and also as the first step in predicting the potential of active compounds in plant [24]. Priyanga et al. and Sowmya et al. indicated that the chemical compounds such as alkaloids, tannins, flavonoids, steroids, terpenoids, and phenolic in plants are natural bioactives [25,26]. Saponins are sedimenting and thickened red blood cells, may bind cholesterol [27], and overcome inflammation [28]. Alkaloids might be used as an analgesic, antispasmodic, and antibacterial [29]. Terpenoids increase glutathione-S-transferase and apoptotic against cancer cells [30], antibacteria by weakening the cell membrane and resulting in the dissolution of microbial cell walls [28].

Table 2: $\mathrm{IC}_{50}$ of twigs and leaves $E$. longifolius extracts

\begin{tabular}{llll}
\hline No & Part of the plant & Solvent & IC $_{\mathbf{5 0}}$ \\
\hline 1 & Twigs & Hexane & $>385$ \\
2 & & Chloroform & $>385$ \\
3 & Ethyl acetate & 15,65 \\
4 & Methanol & 67,24 \\
5 & & Hexane & $>385$ \\
6 & Leaves & Chloroform & $>385$ \\
7 & & Ethyl acetate & 78,59 \\
\hline E. longifolius: Exocarpos longifolius & &
\end{tabular}

Table 3: Identified chemical compounds of ethyl acetate twigs extract of $E$. longifolius

\begin{tabular}{llll}
\hline Retention time (min) & Area & Area percentage (\%) & Compounds \\
\hline 14,18 & 56351 & 0.85 & Phytol, acetate \\
15,11 & 107075 & 1.62 & Methyl palmitate \\
16,79 & 86467 & 1.31 & linoleic acid, methyl ester \\
16,86 & 261350 & 3.96 & Alfa linoleic acid, methyl ester \\
18,20 & 57836 & 0.88 & Sebacic acid, ethyl methyl ester \\
18,36 & 49588 & 0.75 & 2-Isopropenyl-4,4,7a-trimethyl-2,4,5,6,7,7a-hexahydro-benzofuran-6-ol \\
19,55 & 45983 & 0.70 & 1-Dehydrotestosterone, methyloxime, trimethylsilyl ether \\
19,93 & 56051 & 0.85 & Androst-11-en-17-one, 3-formyloxy-, (3.alpha., 5.alpha.)- \\
20,55 & 160571 & 2.43 & Tetracontane-1,40-diol \\
21,55 & 197451 & 2.99 & N1-(8-Methyl-8-azabicyclo[3.2.1]oct-3-yl)-2-(2-methoxyphenyl) acetamide \\
21,58 & 49929 & 0.76 & 4-Acetyloxyimino-6,6-dimethyl-3-methylsulfanyl-4,5,6,7-tetrahydro-benzo[c] \\
& & thiophene-1-carboxylic acid methyl ester \\
21,70 & 1449611 & 21.91 & Stigmast-4-en-3-one
\end{tabular}

E. longifolius: Exocarpos longifolius

Flavonoids have many biological activities, including anti-inflammatory, antibacterial, antiallergic [31,32], antimicrobial, antioxidant, and cytotoxic properties [33].

DPPH free radical is commonly used for evaluation of antioxidant activity because it is a stable radical. DPPH free radical scavenging activity assay has been used widely for plant materials and pure compounds [34] because it's fast, simple [35] and the results are reliable [36]. In the presence of antioxidant compounds, DPPH (purple colored) will be reduced to $\alpha, \alpha$-diphenyl- $\beta$-picryl hydrazine (yellow colored) [37]. The yellow color produced through reduction of DPPH against a purple background on the TLC [38]. The intensity of the color indicates the potential of DPPH free radical scavenging activity. The active extracts as DPPH free radical scavengers may be related to the flavonoids content

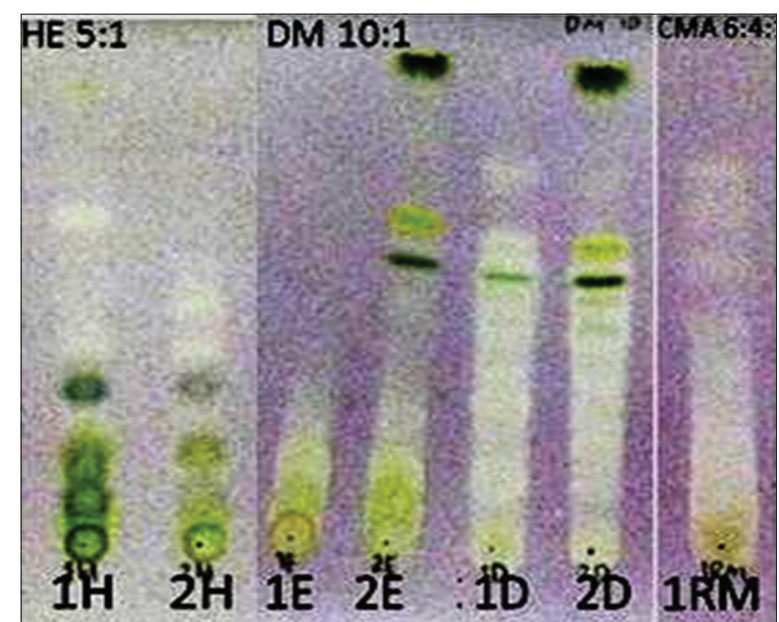

Fig. 1: Chromatogram of Exocarpos longifolius extracts sprayed with $0.2 \%$ 2,2-diphenyl-1-picrylhydrazyl (DPPH) in methanol.

The yellowish-white band shows the active compounds as

DPPH free radical scavengers. (1: Twig, 2: Leaves, H: Hexane, D: Chloroform, E: Ethyl acetate, and RM: Methanol)

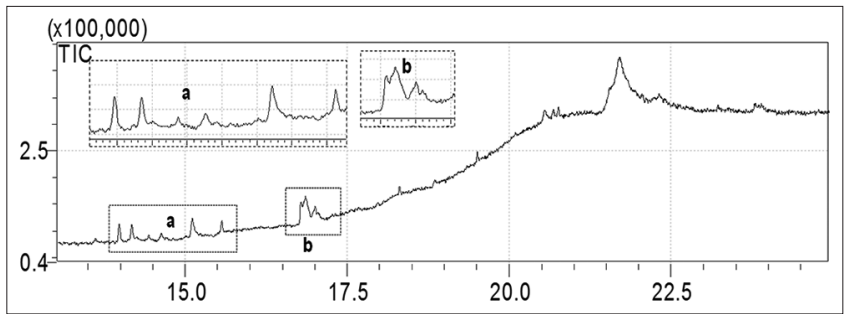

Fig. 2: Gas chromatography-mass spectrometry chromatogram of ethyl acetate extract of Exocarpos longifolius of twigs 
Table 4: Bioactivity of compounds in E. longifolius ethyl acetate extract

\begin{tabular}{|c|c|c|c|}
\hline No & Name of compound & Activity & Ref. \\
\hline 1 & Phytol, acetate & Antimycobacterial & [18] \\
\hline 2 & Methyl palmitate & Acaricidal activity & [19] \\
\hline \multirow[t]{3}{*}{3} & Linoleic acid, methyl ester & $\begin{array}{l}\text { Increase Zinc availability, acidifier, inhibit } \\
\text { production of uric acid }\end{array}$ & [20] \\
\hline & & Anticancer & {$[21]$} \\
\hline & & $\begin{array}{l}\text { Anti-inflammatory, antihistamine, and } \\
\text { anti-arthritic properties. It also possesses } \\
\text { hepatoprotective and hypocholesterolemic } \\
\text { properties }\end{array}$ & [22] \\
\hline 4 & Alpha-linolenic acid, methyl ester & $\begin{array}{l}\text { Increase zinc availability, acidifier, inhibit } \\
\text { production of uric acid }\end{array}$ & [20] \\
\hline 5 & Sebacic acid, ethyl methyl ster & Acidifier, inhibit production of uric acid & [20] \\
\hline 6 & 2-Isopropenyl-4,4,7a-trimethyl-2,4,5,6,7,7a-hexahydro-benzofuran-6-ol & Oligosaccharide provider & [20] \\
\hline 7 & 1-Dehydrotestosterone, methyloxime, trimethylsilyl ether & - & - \\
\hline 8 & Androst-11-en-17-one, 3-formyloxy-, (3.alpha., 5.alpha.)- & $\begin{array}{l}\text { Alpha-amylase inhibitor, alpha-glucosidase } \\
\text { inhibitor }\end{array}$ & [20] \\
\hline 10 & N1-(8-Methyl-8-azabicyclo[3.2.1]oct-3-yl)-2-(2-methoxyphenyl) acetamide & $\begin{array}{l}\text { Antitumor, anaphylactic, inhibit production } \\
\text { of tumor necrosis factor }\end{array}$ & {$[20]$} \\
\hline 11 & $\begin{array}{l}\text { 4-Acetyloxyimino-6,6-dimethyl-3-methylsulfanyl-4,5,6,7-tetrahydro-benzo[c] } \\
\text { thiophene-1-carboxylic acid methyl ester }\end{array}$ & Acidifier, inhibit production of uric acid & [20] \\
\hline 12 & Stigmast-4-en-3-one & Hypoglycemic effect & [23] \\
\hline
\end{tabular}

E. longifolius: Exocarpos longifolius

in the extract. Flavonoids are able as a free radical scavenger [39], act as hydrogen donor [40] and inhibit the enzyme responsible for free radicals generation [41]. Tannins in the ethyl acetate extracts might also contribute to free radical scavenging activity and antibacterial activity [42]. The DPPH radical scavenger activity of the extract serves as an important indicator of its potential as an antioxidant. An antioxidant prevents the oxidation process of the molecule by protecting the key cellular components from free radicals [43].

The active extract was analyzed further to identify its chemical compounds by GC-MS analysis. The compounds from the extract are identified based on interpretation on mass spectrum of GC - MS using the database of National Institute Standard and Technology (NIST11) and WILEY 8. The twelve compounds were characterized and identified (Table 3).

\section{CONCLUSIONS}

Based on the result, it can be concluded that the ethyl acetate extract of $E$. longifolius twigs had strong free radicals scavengers' activity, and the main compounds were Stigmast-4-en-3-one. Further study needs to be done to fractionate, isolate and elucidate the potential natural free radicals scavengers from E. longifolius.

\section{ACKNOWLEDGMENT}

The authors thank Dra. Florentina Indah Windradi for her kind contribution of sample collection from West Nusa Tenggara.

\section{AUTHOR'S CONTRIBUTION}

Praptiwi, designed the work and performed the laboratory analysis for extraction and bioassay, participated in drafting the article and contributed to the final manuscript. Ahmad Fathoni, performed the laboratory analysis in phytochemical analysis and GC-MS, performed for data analysis and interpretation, and contributed to the final manuscript.

\section{CONFLICTS OF INTEREST}

The authors declare that they have no conflicts of interests.

\section{REFERENCES}

1. Kong JM, Goh NK, Chia LS, Chia TF. Recent advances in traditional plant drugs and orchids. Acta Pharmacol Sin 2003;24:7-21.
2. Doughari JH, Ndakidemi PA, Human IS, Benade S. Antioxidant, antimicrobial, antiverotoxic potentials of extracts of Curtisia dentatat. J Ethnopharmacol 2012;141:1041-50.

3. Mahboubi M, Haghi G, Kazempour N, Hatemi AR. Total phenolic content, antioxidant and antimicrobial activities of Blepharis edulis extracts. Songklanakarin J Sci Technol 2013;35:11-6.

4. Jothy SL, Zuraini Z, Sasidharan S. Phytochemical screening, DPPH free radical scavenging and xanthine oxidase inhibitory activities of Cassia fistula seeds extract. J Med Plant Res 2011;5:1941-7.

5. Sandhya B, Manoharan S, Sirisha LG, Manmohan CR. Lipid peroxidation and antioxidant status in prostate cancer patients. Indian J Sci Technol 2010;3:83-6.

6. Romero AC, Hernandez EG, Ceron TF, Chavez A. The exogenous antioxidants. In: Morales-Gonzalez JA, editor. Oxidative Stress and Chronic Degenerative Diseases-A Role for Antioxidants. 1st ed. Ch. 2. Croatia: Intech; 2013. p. 33-58

7. Lobo V, Patil A, Phatak A, Chandra N. Free radicals, antioxidants and functional foods: Impact on human health. Pharmacogn Rev 2010;4:118-26.

8. Vicas SI, Rugina D, Socaciu C. Antioxidant activity of European mistletoe (Viscum album). In: Rao V, editor. Phytochemicals as Nutraceuticals-Global Approaches to their Rolein Nutrition and Health. Rijeka, Croatia: InTec.; 2012. p. 115-30.

9. Sahoo S, Jena S, Sahoo A, Ray A, Nasim N, Kar B, et al. GC-MS analysis and evaluation of bioactivities of Kaempferia parishii-a natural source of totarol. Int J Pharm PharmSci 2016;8:182-6.

10. Koch M, Bugni TS, Pond CD, Sondossi M, Dindi M, Piskaut P, et al. Antimycobacterial activity of Exocarpos latifolius is due to exocarpic acid. Planta Med 2009;75:1326-30.

11. Rached W, Calhelha RC, Fernandes A, Carvalho AM, Bennaceur M, Marouf A, et al. Phytochemical characterization and bioactive properties of Osyris quadripartite Salzm. Ex decne leaves from Algeria. RSC Adv 2016;6:72768-76.

12. Aquino R, Mencherini T, Picem P, Christen P, Villareal P, Delporte C, et al. Antioxidant activity of selected constituents of Quinchamali umchilensis. Int J Pharm Sci Nanotech 2015;8:2775-78.

13. Harborne AJ. Phytochemical Methods a Guide to Modern Techniques of Plant Analysis. $2^{\text {nd }}$ ed. London: Chapman \& Hall; 1984.

14. Anandjiwala S, Bagul MS, Parabia M, Rajani M. Evaluation of free radical scavenging activity of an ayurvedic formulation, Panchvalkala. Indian J Pharm Sci 2008;70:31-5.

15. Zhou X, Choi PS, Yang JM, Or PM, Hoi PM, Lee SM, et al. Chemical and pharmacological evaluations on the extract of Scutellaria baicalensis Georgi (Huang-Qin) prepared by various extraction methods. SpringerPlus 2016;5:1438.

16. Praptiwi, Jamal Y, Fathoni A, Nurkanto A, Agusta A. 3-Acetyl-2,5,7trihydroxy-1,4-naphtalenedione, an antimicrobial metabolite from the 
culture of endophytic fungus coelomycetes TCBP4 from Tinospora crispa. Med Litbangkes 2013;23:95-101.

17. Blois MS. Antioxidant determination by the use of stable free radicals. Nature 1958;181:1199-2000.

18. Rajab MS, Cantrell CL, Franzblau SG, Fischer NH. Antimycobacterial activity of (E)-phytol and derivatives: A preliminary structure-activity study. Planta Med 1998;64:2-4

19. Wang YN, Wang HX, Shen ZJ, Zhao LL, Clarke SR, Sun JH. Methyl palmitate, an acaricidal compound occurring in green walnut husks. J Econ Entomol 2009;102:196-202.

20. Duke JA. Dr Duke's Phytochemical and Ethnobotanical Databases. Maryland: National Agricultural Library,USDA; 2016.

21. Yu FR, Lian XZ, Guo HY, McGuire PM, Li RD, Wang R, et al. Isolation and characterization of methyl esters and derivatives from Euphorbia kansui (Euphorbiaceae) and their inhibitory effects on the human SGC7901 cells. J Pharm PharmSci 2005;8:528-35.

22. Henry GE, Momin RA, Nair MG, Dewitt DL. Antioxidant and cyclooxygenase activities of fatty acids found in food. J Agric Food Chem 2002;50:2231-4

23. Alexander-Lindo RL, Morrison EY, Nair MG. Hypoglycaemic effect of stigmast-4-en-3-one and its corresponding alcohol from the bark of Anacardium occidentale (cashew). Phytother Res 2004;18:403-7.

24. Chew YL, Chan EW, Tan PL, Lim YY, Stanslas J, Goh JK. Assessment of phytochemical content, polyphenolic composition, antioxidant and antibacterial activities of leguminase medicinal plants in peninsular. BMC Complementary Altern Med 2011;11:12.

25. Priyanga S, Hemmalakshmi S, Devaki K. Comparative chromatographyc fingerprint profiles of ethanolic extract of Macrotyloma uniflorum L. Leaves and stem. Int J Pharm Clin Res 2014;6:288-99.

26. Sowmya S, Chella PP, Anusooriya P, Vidya B, Pratibha P, Gopalakrishnan VK. In vitro antioxidant activity, in vivo skin irritation studies and HPTLC analysis of Cayratia trifolia (L.) Domin. Int J Toxicol Pharm Res 2015;7:1-9.

27. Sodipo OA, Akiniyi JA, Ogunbanosu JV. Studies on certain characteristics of extracts of bark of pansinystaliamacruceras (K. Schem) Piere. Exbeile. Glob J Pure Appl Sci 2000;6:83-7.

28. Varughese B, Tripathi J. Phytochemical evaluation of different solvent extracts of aegle marmelosfruit at different stages of its ripening. Adv Life Sci Tech 2013;8:8-12.

29. Stary F. The Natural Guide to Medicinal Herbs, and Plants. London: Tiger Books International; 1998.

30. Dillard CJ, German JB. Phytochemicals: Nutraceiticals and human health. J Sci Food Agric 2000;80:1744-56

31. Cook NC, Samman S. Flavonoids: Chemistry, Metabolism Cardio protective effects, and adietary sources. J Nutr Biochem 1996;7:6-76.

32. Cushnie TP, Lamb AJ. Antimicrobial activity of flavonoids. Int J Antimicrob Agents 2005;26:343-56.

33. Tsuchiya H, Sat M, Miyazaki T, Fujiwara S, Tanigaki S, Ohyama M. Comparative study on the antibacterial activity of phytochemical flavonones against methicillin resistant Staphylococcus aureus. J Ethnopharmacol 1996;50:27-34.

34. Mariod AA, Ibrahim RM, Ismail M, Ismail N. Antioxidant activity and phenolic content of phenolic rich fractions obtained from black cumin (Nigella sativa) seedcake. Food Chem 2009;116:306-12.

35. Bozin B, Mimica-Dukic N, Samojlik I, Goran A, Igic R. Phenolics as antioxidants in garlic (Allium sativum L., Alliaceae). Food Chem 2008;111:925-9.

36. Huang D, Ou B, Prior RL. The chemistry behind antioxidant capacity assays. J Agric Food Chem 2005;53:1841-56.

37. Abdelwahab SI, Mohan S, Mohamed Elhassan M, Al-Mekhlafi N, Mariod AA, Abdul AB, et al. Antiapoptotic and antioxidant properties of Orthosiphon stamineus benth (Cat's whiskers): Intervention in the bcl-2-mediated apoptotic pathway. Evid Based Complement Alternat Med 2011;2011:156765.

38. Kannan R, Arumugam R, Meenakshi S. Thin layer chromatography analysis of antioxidant constituents from seagrasses of gulf of Mannar biosphere reserve, South India. Int J ChemTech Res 2010;2:1526-30.

39. Treml J, Smejkal K. Flavonoids as potent scavengers of hydroxyl radicals. Compr Rev Food Sci Food Saf 2016;15:720-38.

40. Cren-Olive C, Hapiot P, Pinson J, Rolando C. Free radical chemistry of flavan-3-ols: Determination of thermodynamic parameter and of kinetic reactivity from short (ns) to long (ms) time scale. J Am Chem Soc 2002;124:14027-38.

41. Benavente-García O, Castillo J. Update on uses and properties of citrus flavonoids: New findings in anticancer, cardiovascular, and antiinflammatory activity. J Agric Food Chem 2008;56:6185-205.

42. Adamu M, Naidoo V, Ellof JN. The antibacterial activity, antioxidant activity and selectivity index of leaf extracts of thirteen South African tree species used in ethno veterinary medicine to treat helminth infections. BMC Vet Res 2014;10:52.

43. Sundararaj JP, Kuppuraj S, Ganesan A, Ponnusamy P, Nayaka S. In vitro assessment of antioxidant and antimicrobial activities of different solvent extracts from lichen Ramalina nervulosa. Int J Pharm PharmSci 2015;7:200-4 